\title{
Underweight is associated with mortality in patients with severe sepsis and septic shock
}

\author{
SM Lee ${ }^{1 *}$, JW Kang ${ }^{1}$, YH Jo ${ }^{1}$, K Kim$^{1}$, JH Lee ${ }^{1}$, J Lee $^{1}$, KP Rim $^{2}$ \\ From ESICM LIVES 2015 \\ Berlin, Germany. 3-7 October 2015
}

\section{Introduction}

It is well known that obesity is associate with improved mortality in severe sepsis in western countries. However, the prognosis of the patients with sepsis in Asian countries might be different from that of western countries.

\section{Objectives}

This study was performed to investigate the association of the body mass index (BMI) with the mortality in patients with severe sepsis and septic shock in an Asian country.

\section{Methods}

A retrospective analysis of prospectively collected database of patients with severe sepsis and septic shock was performed. We classified the patients into four groups according to the basic criteria of the World Health Organization (WHO) guidelines as follows, underweight, < 18.5; normal, 18.5-24.99; overweight, 25-29.99; obesity, $\geq 30 \mathrm{~kg} / \mathrm{m}^{2}$, respectively. The multivariate logistic regression was performed to investigate the association of BMI with 28-day mortality adjusting for the demographic data, comorbidities, laboratory results and Acute Physiologic and Chronic Health Evaluation II score.

\section{Results}

A total of 1022 patients were included and the overall mortality was $20.6 \%$. The mortality was $30.6 \%$ in underweight, $18.5 \%$ in normal, $17.1 \%$ in overweight, and $14.3 \%$ in obesity, respectively $(\mathrm{p}<0.05)$. In the multivariate analysis, underweight is independently associated with mortality compared with normal BMI (odds ratio (OR), 1.63; 95\% CI, 1.12-2.37). However, overweight and obesity are not

'Seoul National University Bundang Hospital, Emergency Medicine, Seongnam, Korea, Republic of Korea

Full list of author information is available at the end of the article associate with mortality (OR, 0.913; 95\% CI 0.63-1.51 and OR, 0.59; 95\% CI, 0.24-2.25, respectively).

\section{Conclusions}

Underweight is associated with 28-day mortality and obesity is not associated with the prognosis in patients with severe sepsis and septic shock in an Asian country.

\section{Authors' details}

'Seoul National University Bundang Hospital, Emergency Medicine, Seongnam, Korea, Republic of Korea. ${ }^{2}$ St. Carollo General Hospital, Emergency Medicine, Suncheon, Korea, Republic of Korea.

Published: 1 October 2015

\section{Reference}

1. WHO: Physical status: the use and interpretation of anthropometry. Report of a WHO Expert Committee. WHO Technical Report Series 854 Geneva: World Health Organization; 1995.

\section{doi:10.1186/2197-425X-3-S1-A876}

Cite this article as: Lee et al:: Underweight is associated with mortality in patients with severe sepsis and septic shock. Intensive Care Medicine Experimental 2015 3(Suppl 1):A876.

\section{SpringerOpen $^{\circ}$}

(c) 2015 Lee et al.; This is an Open Access article distributed under the terms of the Creative Commons Attribution License (http:// creativecommons.org/licenses/by/4.0), which permits unrestricted use, distribution, and reproduction in any medium, provided the original work is properly cited.

Submit your manuscript to a SpringerOpen ${ }^{\circ}$ journal and benefit from:

- Convenient online submission

- Rigorous peer review

- Immediate publication on acceptance

- Open access: articles freely available online

- High visibility within the field

Retaining the copyright to your article

Submit your next manuscript at $>$ springeropen.com 